\title{
Increased presence of Epstein-Barr virus DNA in ocular fluid samples from HIV negative immunocompromised patients with uveitis
}

Jenny V Ongkosuwito, Allegonda Van der Lelij, Marcel Bruinenberg, Marian Wienesen-van Doorn, Eric J C Feron, Carel B Hoyng, Rob J W de Keizer, Anne-Marie Klok, Aize Kijlstra

\section{Department of Ophthalmology, Academic Medical Centre, University of Amsterdam, Netherlands J V Ongkosuwito A Kijlstra}

Department of Ophthalmo-Immunolog The Netherlands Ophthalmic Research Institute, Netherlands J V Ongkosuwito M Bruinenberg

$M$ Wienesen-van Doorn

A-M Klok

A Kijlstra

F C Donders Institute for Ophthalmology, University Hospital Utrecht, Netherlands A Van der Lelij

Eye Hospital Rotterdam, Netherlands E J C Feron

Department of Ophthalmology, University Hospital Nijmegen, Netherlands C B Hoyng

Department of Ophthalmology, University Hospital Leiden, Netherlands R J W de Keizer

Department of Ophthalmology, Hospital of the Free University of Amsterdam,

Netherlands A-M Klok

Correspondence to: Jenny V Ongkosuwito, MD, Department of Ophthalmo-Immunology, Netherlands Ophthalmic Research Institute, PO Box 12141, 1100 AC Amsterdam, Netherlands.

Accepted for publication 10 October 1997
Abstract

Aims-To investigate whether routine testing for Epstein-Barr virus (EBV) is necessary in the examination of a patient with uveitis.

Methods-Intraocular EBV DNA was determined in 183 ocular fluid samples taken from patients with AIDS and uveitis, HIV negative immunocompromised uveitis, acute retinal necrosis, toxoplasma chorioretinitis, intraocular lymphoma, anterior uveitis, and miscellaneous uveitis of unknown cause. In 82 samples from this group of patients paired serum/ocular fluid analysis was performed to detect local antibody production against EBV. Controls $(n=46)$ included ocular fluid samples taken during surgery for diabetic retinopathy, macular pucker, or cataract. Results-Serum antibody titres to EBV capsid antigen proved to be significantly increased in HIV negative immunocompromised patients with uveitis $(\mathbf{p}<0.01)$ compared with controls. Local antibody production revealed only three positive cases out of 82 patients tested, two results were borderline positive and one patient had uveitis caused by VZV. EBV DNA was detected in three out of 46 control ocular fluid samples. In the different uveitis groups EBV DNA was noted, but was not significantly higher than in the controls, except in six out of 11 HIV negative immunocompromised patients $(p=0.0008)$. In four out of these six cases another infectious agent (VZV, HSV, CMV, or Toxoplasma gondii) had previously been identified as the cause of the uveitis.

Conclusions-When comparing various groups of uveitis patients, EBV DNA was found more often in HIV negative immunocompromised patients with uveitis. Testing for EBV does not have to be included in the routine management of patients with uveitis, since indications for an important role of this virus were not found in the pathogenesis of intraocular inflammation.

(Br f Ophthalmol 1998;82:245-251)

The Epstein-Barr virus (EBV) is a member of the herpes virus group. It is an ubiquitous virus and the majority of the adult population has been infected. Individuals are usually infected through saliva during adolescence and display symptoms such as pharyngitis, fever, and lymphadenopathy. The presence of atypical lymphocytes in a blood smear is characteristic of EBV infection, hence its name of "infectious mononucleosis". It is often a self limiting disease and in most cases infection passes asymptomatically. ${ }^{1}$ After primary infection, a large pool of infected B lymphocytes is generated, the number of which gradually reduces once host cell immunity develops. After infection, latent EBV remains present in approximately one of $10^{6} \mathrm{~B}$ lymphocytes. ${ }^{2}$ The humoral immune response is mainly directed against the virus capsid antigen (VCA) and Epstein-Barr nuclear antigen (EBNA) and remains detectable throughout life. ${ }^{3}$

The cellular immune response to EBV is mediated by both cytotoxic and helper T cells. ${ }^{3}$ EBV specific $T$ cells can be suppressed or inhibited due to immunodeficiency allowing EBV to reactivate, resulting in proliferation of virus particles, as has been noted in AIDS patients ${ }^{4}$ and in patients, who underwent organ transplantation followed by immunosuppressive therapy. ${ }^{5}$ EBV has also been associated with the development of Burkitt's lymphoma in African children, with nasopharyngeal carcinoma in the middle aged population in southern China, with lymphoma in immunocompromised patients (AIDS, transplantation patients), and with Hodgkin's disease. ${ }^{1}$

The role of EBV in the pathogenesis of ocular disease is still controversial. It has been associated with a variety of symptoms, such as conjunctivitis, keratitis, ${ }^{6}$ uveitis, ${ }^{78}$ choroiditis, ${ }^{9}$ and retinitis. ${ }^{10}$ In these reports, the diagnosis was based on virus culture from conjunctival or tear samples, or substantiated by serological findings in serum. Only one group has provided evidence of intraocular EBV antibody synthesis in three immunocompetent patients with bilateral anterior uveitis, and no evidence of infectious mononucleosis. ${ }^{8}$ The authors suggested that EBV uveitis might be a new clinical entity.

So far, the evidence for a possible role of EBV in the pathogenesis of uveitis is mainly based on serological evidence. With the availability of more specific laboratory techniques such as polymerase chain reaction (PCR) for the identification of infectious agents during intraocular inflammation we decided to investigate the role of EBV in uveitis and more specifically whether routine testing for this virus is useful in the laboratory examination of a patient with uveitis. Our 
findings have not yet pointed to a direct role of EBV in uveitis, but did reveal EBV DNA to be present more often in the eyes of HIV negative immunocompromised patients with uveitis than in the eyes of controls.

\section{Patients and methods}

In our study, uveitis was diagnosed according to the criteria of the International Uveitis Study Group ${ }^{11}$ and the research committee of the American Uveitis Society. ${ }^{12}$ Aqueous humour (AH) samples (100-200 $\mu \mathrm{l}$ ) were collected by paracentesis for diagnostic purposes. Vitreous fluid (VF) samples (200-1000 $\mu \mathrm{l})$ were collected during a therapeutic or diagnostic vitrectomy. A venous blood sample was collected at the time of paracentesis or vitrectomy, and serum was obtained after clotting. In some cases another venous blood sample was taken in a tube with $0.34 \mathrm{M}$ EDTA to obtain peripheral blood leucocytes (PBLs). Erythrocytes were lysed by adding three times the volume of the venous blood sample of lysis buffer (150 $\mathrm{mM} \mathrm{NH}_{4} \mathrm{Cl}, 10 \mathrm{mM} \mathrm{KHCO}, 1 \mathrm{mM}$ EDTA). After lysis of erythrocytes the sample was centrifuged at $450 \mathrm{~g}$ and the pellet of PBLs washed with phosphate buffered saline (PBS). The PBL sample was centrifuged at $10000 \mathrm{~g}$ for 15 seconds and the remaining pellet stored at $-70^{\circ} \mathrm{C}$ until use.

We investigated 183 ocular fluid samples from the following patient groups: AIDS, 32; HIV negative immunocompromised, 11; acute retinal necrosis, 24; toxoplasma chorioretinitis, 45; intraocular lymphoma, 11; anterior uveitis, 32; and miscellaneous uveitis with unknown cause, 28 .

Of the 32 patients with AIDS, 27 had a clinical picture of cytomegalovirus (CMV) retinitis, that was confirmed by PCR in 21 cases. The five other patients had, respectively, panuveitis caused by HSV, toxoplasma chorioretinitis, progressive outer retinal necrosis (PORN), papillitis of unknown cause and in one patient no details were available concerning the clinical picture.

As controls we used samples obtained during vitreoretinal surgery of 46 patients with diabetic retinopathy, macular pucker, vitreous haemorrhage, retinal detachment, epiretinal membrane, or cataract. The mean age of patients and controls is shown in Table 1. Patients were informed about the procedures and their consent was obtained.

All ocular fluid samples were tested for the presence of EBV DNA by PCR. From the group of 183 patients, EBV antibody detection was performed on 82 paired ocular and serum samples (AIDS, 21; anterior uveitis, 11; acute retinal necrosis, 16; miscellaneous uveitis, 8; HIV negative immunocompromised, 10 ; intraocular lymphoma, 9; toxoplasma chorioretinitis, 7) Paired EBV antibody analysis was also performed on 20 control samples. From 22 patients we only tested the EBV antibody titre in their serum. These samples were aselectively chosen from our serum bank to match the size of the different groups in which antibodies against EBV were tested. Serum antibody levels against EBV were thus available from 104 patients of the original group of 183 . EBV DNA PCR analysis was also performed in 11 serum samples from the HIV negative immunocompromised patients with uveitis and in available PBL samples $(n=17)$ from all patient groups (see Table 1).

\section{POLYMERASE CHAIN REACTION}

DNA was isolated from intraocular fluid samples according to the method of Boom et $a l .{ }^{13}$ In short, samples $(35-100 \mu \mathrm{l})$ were lysed in $0.1 \mathrm{M}$ TRIS, $0.003 \mathrm{M} \mathrm{HCl}, 10 \mathrm{M}$ guanidinium thiocyanate, $0.036 \mathrm{M}$ EDTA ( $\mathrm{pH} 8.0$ ), $2.6 \%$ Triton X-100, and incubated with $40 \mu$ silicon dioxide beads. Subsequently, the suspension was washed twice with $0.1 \mathrm{M}$ TRIS, $0.003 \mathrm{M}$ $\mathrm{HCl}, 10 \mathrm{M}$ guanidinium thiocyanate, then twice with $70 \%$ ethanol and once with acetone. After washing, the DNA was eluted from the beads in distilled water, while shaking at $56^{\circ} \mathrm{C}$ for 10 minutes, using $20 \mu \mathrm{l}$ more than the volume from which it originated. DNA from serum and PBL samples was isolated in the same way, but DNA was eluted from the beads using half the volume from which it originated plus $20 \mu \mathrm{l}$ of distilled water. For detection of EBV DNA we chose primers encoded in the BAM-H1-W fragment (EMBL accession number: J02072), since the Bam-H1-W fragment is repeated 10 times in the EBV genome. ${ }^{14}$ The primer sequence we used was:

Table 1 Detection of intraocular antibody production against EBV and results of PCR for EBV DNA in patients with uveitis

\begin{tabular}{|c|c|c|c|c|c|c|}
\hline \multirow[b]{2}{*}{ Diagnosis } & \multirow[b]{2}{*}{$\operatorname{Sex} M / F$} & \multirow{2}{*}{$\begin{array}{l}\text { Mean age (years) } \\
\text { (range) }\end{array}$} & \multicolumn{2}{|c|}{$\begin{array}{l}\text { EBV DNA present in } \\
\text { ocular fluid sample } \\
\text { (PCR) }\end{array}$} & \multirow{2}{*}{$\begin{array}{l}\text { EBV DNA present } \\
\text { in } P B L^{\star} \text { sample } \\
(P C R)\end{array}$} & \multirow{2}{*}{$\begin{array}{l}\text { Positive GWt } \\
\text { coefficient to } \\
E B V\end{array}$} \\
\hline & & & Aqueous & Vitreous & & \\
\hline AIDS $(n=32)$ & $27 / 5$ & $40(27-88)$ & $2 / 25$ & $1 / 7$ & $7 / 17$ & $0 / 21$ \\
\hline \multicolumn{7}{|l|}{ HIV negative immunocom- } \\
\hline Acute retinal necrosis $(n=24)$ & $11 / 13$ & $49.8(27-89)$ & $\begin{array}{l}1 / 4+ \\
0 / 11\end{array}$ & $\begin{array}{l}J / 1+ \\
1 / 13\end{array}$ & $0 / 2$ & $0 / 16$ \\
\hline \multicolumn{7}{|l|}{ Toxoplasma chorioretinitis } \\
\hline$(n=45)$ & $25 / 20$ & $36.1(8-47)$ & $3 / 28$ & $1 / 17$ & $1 / 5$ & $0 / 7$ \\
\hline Intraocular lymphoma $(n=11)$ & $7 / 4$ & $59.9(23-75)$ & $0 / 2$ & $3 / 9$ & $0 / 1$ & $0 / 9$ \\
\hline Anterior uveitis $(n=32)$ & $12 / 20$ & $45.8(7-83)$ & $3 / 31$ & $0 / 1$ & $0 / 3$ & $0 / 11$ \\
\hline \multicolumn{7}{|l|}{ Miscellaneous uveitis $(n=28)$} \\
\hline (unknown cause) & $10 / 18$ & $43.6(8-79)$ & $3 / 17$ & $2 / 11$ & $0 / 0$ & $2 / 8$ \\
\hline Controls $(n=46)$ & $23 / 23$ & $59.6(22-81)$ & $0 / 9$ & $3 / 37$ & $0 / 0$ & $0 / 20$ \\
\hline Total $(n=229)$ & $122 / 107$ & & $12 / 127$ & $16 / 102$ & $9 / 31$ & $3 / 102$ \\
\hline
\end{tabular}

The data indicate the number of positive samples over total number tested ${ }^{\star} \mathrm{PBL}=$ peripheral blood leucocyte; $+\mathrm{GW}=\mathrm{Goldmann}-$ Witmer; $\neq p$ value of aqueous and vitreous samples together calculated by Fisher's exact test $=0.008$. 
5' primer: CTC TGG TAG TGA TTT GGA CC nucleotide location 781

3' primer: GTG AAG TCA CAA ACA AGC CC nucleotide location 1001.

The expected size of the amplified product was 240 base pairs.

To prevent carryover contamination with PCR products from previous reactions we used uracil DNA glycosilase and dNTPs (dTTP was replaced by dUTP) according to Longo et $a l .{ }^{15}$ Other precautions included the use of filtertips and separate rooms for isolating DNA, preparing the PCR mixture and running the PCR.

The PCR mixture $(50 \mu \mathrm{l})$ contained: $50 \mathrm{mM}$ $\mathrm{KCl}, 10 \mathrm{mM}$ TRIS (pH 8.3), $10 \mu \mathrm{g}$ of bovine serum albumin, $2.0 \mathrm{mM} \mathrm{MgCl}, 0.4 \mathrm{pmol}$ of each primer, $0.2 \mathrm{pmol}$ of dUTP (Sphaero Q, Leiden), 0.2 pmol each of dGTP, dATP, dCTP (Pharmacia), 1 unit of Ampli-Taq DNA Polymerase (Perkin Elmer), 0.1 unit of uracil DNA glycosilase (Life Technologies), $5 \mu \mathrm{l}$ of isolated DNA solution, and distilled $\mathrm{H}_{2} \mathrm{O}$ was added to a total volume of $50 \mu \mathrm{l}$. The PCR was run in a Biometra Trio Thermoblock (Westburg, Leusden), using the following cycling regimen: 10 minutes at $37^{\circ} \mathrm{C}, 5$ minutes at $95^{\circ} \mathrm{C}$, then 40 cycles were performed as follows: 30 seconds at $95^{\circ} \mathrm{C}, 30$ seconds at the optimal annealing temperature $\left(58^{\circ} \mathrm{C}\right)$, and 1 minute at $72^{\circ} \mathrm{C}$. After the last cycle the samples were incubated for 7 minutes at $72^{\circ} \mathrm{C}$ for final elongation.

A volume of $10 \mu \mathrm{l}$ of the PCR product was run on a $1.8 \%$ agarose gel containing ethidium bromide. Bands were visualised by ultraviolet light, and to preserve the results the gel was photographed. In some cases gels underwent Southern blotting. DNA was transferred to a positively charged nylon membrane (Qiagen, Westburg, Leusden) and hybridised with a ${ }^{32} \mathrm{P}$ labelled oligonucleotide probe specific for the product formed (GAA GCG GGT CTA TGG TTG GCT GCG CTG nucleotide location 925). ${ }^{14}$

EBV primer specificity was tested on samples containing DNA isolated from Toxoplasma RH strain tachyzoites, from human fibroblasts infected with cytomegalovirus strain $\mathrm{AD}$ 169,

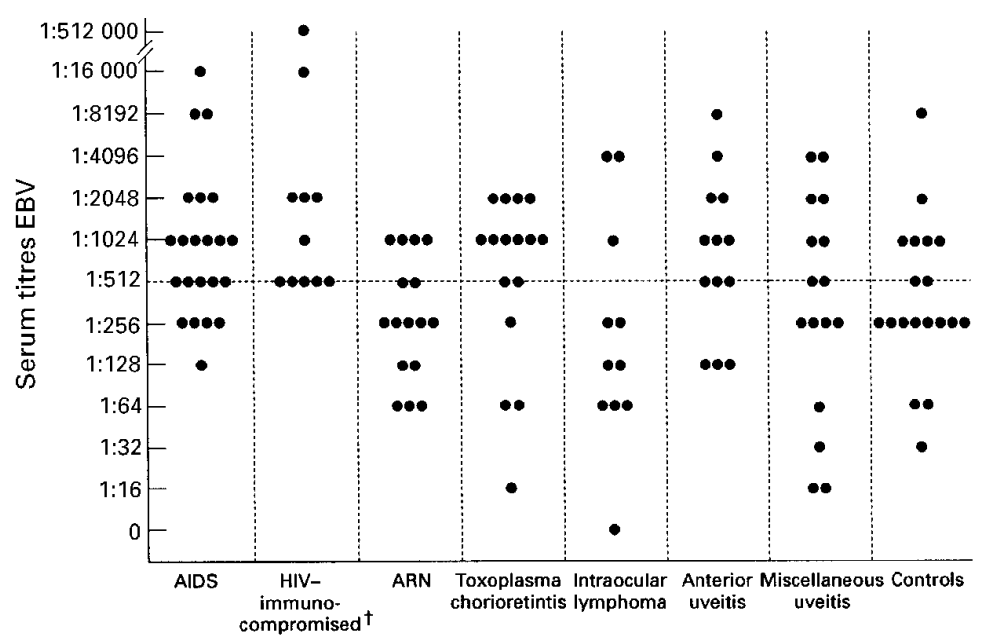

Figure 1 Serum titres against EBV as measured by immunofluorescence assay. tp value calculated by Fisher's exact test $=0.001$ from varicella zoster virus, and from herpes simplex virus type 1 strains. No cross reactivity was observed. DNA isolated from an EBV transformed B cell line was used as a positive control.

DNA from varicella zoster virus (VZV), herpes simplex virus type 1 (HSV-1), cytomegalovirus (CMV) and Toxoplasma gondii was detected as described previously by de Boer et $a l .{ }^{16}$ The detection limit for each agent, determined by using known amounts of plasmid containing target DNA, was varicella zoster virus, 20 copies; cytomegalovirus, 20 copies; herpes simplex virus type 1, 35 copies; Epstein-Barr virus: 20 copies; and Toxoplasma gondii, 30 copies.

The presence of DNA in the various isolates was verified using a PCR for $\beta$ globin as described elsewhere. ${ }^{17}$

SEROLOGY

Determination of intraocular IgG antibody production against $\mathrm{CMV}, \mathrm{HSV}, \mathrm{VZV}, \mathrm{EBV}$, and Toxoplasma gondii was performed according to techniques described elsewhere. ${ }^{16}$ IgG antibodies detected in the immunofluorescence assay for EBV (Gull Laboratories, Inc, Salt Lake City, UT, USA) are mainly directed to the EBV capsid antigen. Local intraocular antibody production was considered to be present when the Goldmann-Witmer (GW) coefficient was higher than 3.0.18

During data analysis a cut off value of 1:512 was taken to indicate an increased serology.

\section{STATISTICS}

Statistical analysis of the data was performed using the $\chi^{2}$ test and the Fisher's exact test. Cumulation of type I errors was corrected for by taking $\alpha=0.01$.

\section{Results}

\section{SEROLOGY}

To evaluate the role of EBV in the pathogenesis of uveitis, the serum IgG antibody level to EBV CA (capsid antigen) was tested in uveitis patients and controls (Fig 1). When a cut off value of 1:512 was taken, the serum titres were significantly increased compared with controls in the HIV negative immunocompromised patients $(p=0.002)$. All HIV negative immunocompromised patients $(n=11)$ had a titre $\geqslant 1: 512$ to EBV compared with eight out of 18 controls. All other groups of uveitis patients tested did not have significantly raised EBV titres in their blood compared with controls.

To further investigate the role of EBV in uveitis we also investigated local intraocular antibody production against this virus. Local EBV antibody production was not found in the controls tested $(n=20$; diabetic retinopathy, nine; cataract, six; vitreous haemorrhage, three; retinal detachment, one; and epiretinal membrane, one). On the other hand, local antibody production to EBV could be detected in three out of 82 uveitis samples (Table 1). Of these three positive patients one (female, 26 years, GW coefficient for EBV 3.8) belonged to the HIV negative immunocompromised patients and had a clinical diagnosis of choroiditis 
during a rejection period of her kidney transplant. Diagnostic tests for other infectious causes (Toxoplasma gondii, CMV, HSV, and VZV) were negative in this patient. The other two patients showing local EBV antibody production belonged to the group of miscellaneous uveitis patients. One young patient (male, 9 years, GW coefficient for EBV 5.6) had posterior uveitis and also showed local antibody production to VZV (GW coefficient for VZV 11.3). The third patient (female, 63 years, GW coefficient for EBV 3.6) suffered from intermediate uveitis and did not have a positive test to other infectious agents. Of these three patients, only the kidney transplant recipient with choroiditis had an elevated serum antibody titre $(1: 2048)$ against EBV. None of the patients showing local EBV antibody production had detectable intraocular EBV DNA.

From the data described above, the conclusion was made that serological screening for EBV did not provide conclusive evidence for a major role of this virus in the pathogenesis of ocular inflammation in our patient groups.

POLYMERASE CHAIN REACTION

Since serology only provides indirect evidence for a causal relation between an infectious agent and inflammation, we also used nonserological methods to detect EBV in the eyes of uveitis patients. We therefore isolated DNA from ocular fluids of various uveitis patients and controls, and performed a PCR for an EBV DNA fragment that is known to occur at least 10-fold in the genome of this virus.

The EBV PCR results are shown in Table 1. EBV DNA was detectable in three vitreous samples out of 46 control samples (nine aqueous, 37 vitreous). No DNA of other infectious agents (Toxoplasma gondii, CMV, HSV-1, and VZV) could be detected in these controls. None of the controls was known to use any immunosuppressive medication.

Compared with the controls, the presence of EBV DNA was only significantly increased in samples of the HIV negative immunocompromised patient group ( $\mathrm{p}<0.0008)$. Six out of 11 patients in this group had detectable EBV DNA in their ocular fluids (five of seven vitreous and one of four aqueous samples).

In four out of these six patients another infectious agent could be detected either by measurement of local antibody production or by PCR. The details of these patients were as follows (see Table 2):

Patient 1 (female, 27 years) had systemic lupus erythematosus (SLE) and was treated with high doses of azathioprine and pulse doses of corticosteroids because of exacerbation of her SLE (November 1992). In March 1993, the SLE was in remission but the patient was still using azathioprine. She developed a bilateral retinitis and vasculitis. The clinical diagnosis was CMV retinitis which was confirmed by PCR and local antibody production (GW coefficient for CMV 4.0).

Patient 3 (male, 62 years) had received a heart transplant in 1993. In March 1994 he developed a clinical picture of CMV retinitis which was confirmed by PCR and local antibody production (GW coefficient for CMV 4.6).

Patient 5 (male, 55 years) had received a heart transplant in November 1993. After $21 / 2$ months of complaints, the patient went to the ophthalmologist in September 1994 and showed a clinical picture of a possible CMV retinitis and therefore a diagnostic vitrectomy was done. Laboratory tests were performed for CMV, HSV-1, and VZV. The GW coefficient revealed local antibody production against HSV (6.1) with a negative PCR result for HSV-1 DNA. The patient was treated with acyclovir, but the clinical picture did not resolve. In October 1994 a retinal detachment was seen and the patient underwent a pars plana vitrectomy whereby a circling band was placed, membranes were removed, and the vitreous fluid was replaced by silicon oil. Part of the vitreous fluid was used to evaluate the inflammation. Laboratory tests were performed for the herpes viruses and Toxoplasma gondii. The GW coefficient for HSV had decreased $(<1)$. Testing for Toxoplasma gondii revealed local antibody production (GW coefficient 3.0) and a positive PCR for $T$ gondii. The remainder of the first vitreous fluid sample was subsequently tested for $T$ gondii and showed a GW coefficient of 12.1 as well as a positive PCR.

Patient 8 (male, 14 years) suffered from leukaemia. During his first chemotherapy he developed a clinical picture of acute retinal necrosis caused by varicella zoster virus (GW coefficient for VZV 7.1).

Table 2 Clinical details and laboratory test results in the group of HIV negative immunocompromised patients with uveitis

\begin{tabular}{|c|c|c|c|c|c|c|}
\hline $\begin{array}{l}\text { Patient no, sex, } \\
\text { age (years) }\end{array}$ & Diagnosis & Ocular diagnosis & Sample & Positive $G W$ & $\begin{array}{l}\text { Immunosuppressive } \\
\text { medication }\end{array}$ & Positive PCR for \\
\hline $1, F, 27$ & SLE & CMV retinitis & VF & $\mathrm{CMV}=4$ & Aza & CMV/EBV \\
\hline $2, M, 47$ & Non-Hodgkin's lymphoma & CMV retinitis & VF & $\mathrm{CMV}=7.2$ & CHOPP & None \\
\hline $3, M, 62$ & Heart transplantation & $\mathrm{CMV}$ retinitis & VF & $\mathrm{CMV}=4.6$ & CsA/pred/Aza & EBV \\
\hline $4, M, 63$ & Heart transplantation & Toxoplasma chorioretinitis & VF & None & $\mathrm{CsA} / \mathrm{pred} / \mathrm{Aza}$ & EBV $(\text { Toxo })^{\star}$ \\
\hline $5, M, 55$ & Heart transplantation & Toxoplasma chorioretinitis & VF & Toxo $=3.0$ & $\mathrm{CsA} / \mathrm{pred} / \mathrm{Aza}$ & Toxo/EBV \\
\hline $6, F, 35$ & NHL (BM transplantation) & Toxoplasma chorioretinitis & $\mathrm{AH}$ & Toxo $=3.1$ & CsA/Aza & Toxo \\
\hline $7, M, 59$ & Kidney transplantation & VZV acute retinal necrosis & $\mathrm{AH}$ & None & Aza/dexamethasone & VZV \\
\hline $8, \mathrm{M}, 14$ & Leukaemia & VZV acute retinal necrosis & VF & $\mathrm{VZV}=7.1$ & Ara C/dacrorubiane & EBV \\
\hline $9, \mathrm{~F}, 26$ & Kidney transplantation & Choroiditis & $\mathrm{AH}$ & $\mathrm{EBV}=3.8$ & Aza/pred & None \\
\hline $10, M, 42$ & Hodgkin's lymphoma & Anterior uveitis & $\mathrm{AH}$ & None & Not mentioned & EBV \\
\hline $11, \mathrm{~F}, 55$ & Mammacarcinoma & Uveitis & VF & None & Dexamethasone & None \\
\hline
\end{tabular}

$\mathrm{AH}=$ aqueous humour; $\mathrm{VF}=$ vitreous fluid; $\mathrm{CsA}=$ cyclosporin $\mathrm{A} ; \mathrm{Aza}=$ azathioprine; Pred = prednisone; Ara $\mathrm{C}=$ cytarabine; $\mathrm{CHOPP}=$ cyclophosphamide, doxorubicin, vincristine, prednisone; $\mathrm{NHL}=$ non-Hodgkin's lymphoma; $\mathrm{BM}=$ bone marrow.

*A previously taken ocular fluid sample had a positive result for Toxoplasma DNA. 


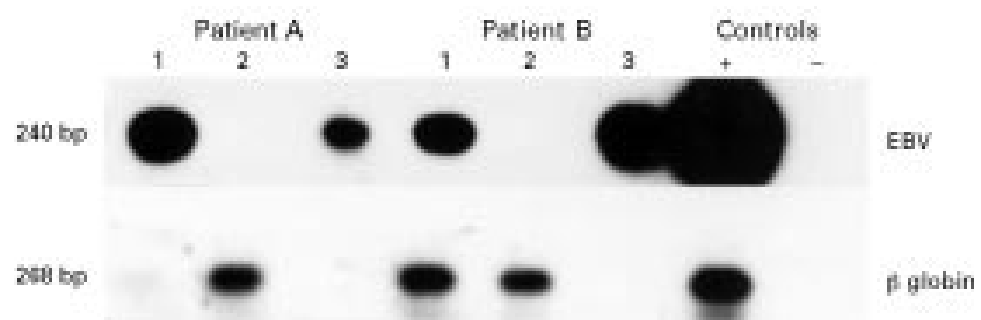

Figure 2 Comparative detection of EBV DNA and $\beta$ globin DNA detection in ocular fluid and PBL sample from two patients positive for EBV DNA in both ocular fluid and PBL sample. Patient A: HIV positive immunocompromised patient; patient B: HIV negative immunocompromised patient (no 5). 1, ocular fluid sample; 2, PBL sample, diluted 1:100; 3, PBL sample undiluted (not tested for $\beta$ globin).

Of the two patients, who were exclusively positive for intraocular EBV DNA one was clinically diagnosed as having toxoplasma chorioretinitis and the other having anterior uveitis with unknown cause. The details of these patients were as follows.

Patient 4 (male, 63 years) who had received a heart transplant 6 months earlier, was diagnosed as having toxoplasma chorioretinitis. Ocular fluid samples taken at that time confirmed the diagnosis: local antibody production against $T$ gondii (GW coefficient 7.7) and $T$ gondii DNA could be detected. After 8 weeks, maintenance therapy (pyrimethamine and folinic acid) was instituted and visual acuity restored from $3 / 60$ to 1.0 in about 3 months. Despite the maintenance therapy, the visual acuity decreased to 0.25 in another 3 months, due to vitreous opacities. The previous toxoplasma chorioretinitis scars were completely quiet. A diagnostic pars plana vitrectomy was performed, since intraocular lymphoma was suspected. At that time his general medication consisted of prednisone, cyclosporine, and azathioprine among others. Intraocular lymphoma could not be confirmed in the vitreous fluid by cytological examination. A negative GW coefficient $(<3)$ and PCR test did not support a diagnosis of active toxoplasma chorioretinitis. PCR tests for CMV, HSV-1, VZV, T gondii were all negative but the PCR test for EBV was positive.

Patient 10 (male, 42 years) suffering from Hodgkin's disease, had a clinical diagnosis of anterior uveitis. No other infectious agents were detectable in his ocular fluid sample. This patient had a very high titre to EBV (>1:512.000 in serum).

In the HIV positive immunocompromised patient group three out of 32 patients had EBV DNA in their eye (not significantly different compared with controls). In these three cases another infectious cause was proved-CMV, HSV, and $T$ gondii, respectively.

As already mentioned above, none of the patients with a positive Goldmann-Witmer coefficient against EBV had EBV DNA in their eyes. Furthermore, no association could be found between serum EBV antibody levels and a positive EBV DNA result in the ocular fluid samples.

To investigate whether the presence of EBV DNA in the eye is caused by "overflow" out of the peripheral circulation, PCR was done on serum and PBL samples. Analysis of EBV DNA in serum (11 samples from the HIV negative immunocompromised patient group) revealed only one positive sample, patient 10 , who also had a very high level of EBV CA antibody titre $(>1: 512000)$ and EBV DNA in his eye. In this patient the presence of EBV DNA in the eye could be due to overflow from the circulation.

PBL samples were not routinely investigated during the examination of patients with uveitis, and were therefore available in only 31 of the 183 patients included in this study. DNA was isolated from the samples and tested for the presence of EBV DNA. EBV DNA was found in nine out of $31 \mathrm{PBL}$ samples tested (Table 1). In this selected group of 31, five cases had EBV DNA in their eye, of whom two were also positive in their PBL sample. One of these patients was from the HIV positive patient group and one was from the HIV negative patient group (patient 5, toxoplasma chorioretinitis).

To investigate if the positive signal of the ocular fluid sample was caused by "overflow" from the peripheral blood circulation, the ocular fluid and PBL sample from these two patients were tested for EBV DNA in the same PCR. The same was done for $\beta$ globin DNA to correct for the amount of cells in the ocular fluid sample and the PBL sample. Although the signals for $\beta$ globin DNA were almost the same, the signal for EBV DNA in both ocular fluid samples was clearly more positive than in the PBL samples (Fig 2). This indicates local proliferation of the virus in the eyes of these patients.

\section{Discussion}

We investigated the role of EBV testing in the management of uveitis in a number of patient groups and observed that only the HIV negative immunocompromised patients with uveitis had a higher incidence of EBV DNA in their ocular fluids than the controls. EBV DNA was found in $54 \%$ of HIV negative immunocompromised patients compared with $9 \%$ in AIDS patients with uveitis and this latter group was not different from controls $(8 \%)$. Systemic reactivation of EBV has been described for the HIV negative and HIV positive immunocompromised patients groups, but to our knowledge no comparative study has been reported concerning viral load in patients with acquired immunodeficiencies. ${ }^{19}$ HIV negative immunocompromised patients differ from HIV positive patients in the mechanisms responsible for immunosuppression. Immunosuppression due to medication (chemotherapy, immunosuppressive drugs) may follow another mechanism than immunosuppression due to infection with HIV.

To our knowledge, this is the first report investigating the presence of intraocular EBV DNA and intraocular EBV antibody production in a large group of uveitis patients. Analysis of local antibody production against EBV only revealed three positive cases out of 82 patients tested, whereby two results were borderline positive. The remaining positive patient also had a GW coefficient for VZV. Whether this was due to a double infection or cross reactivity between these two herpes viruses remains an open question. From these 
results we have concluded that routine testing for intraocular EBV antibody production in a general uveitis population has no additional value in the examination of these patients. Usui and Sakai ${ }^{8}$ described a typical clinical picture of anterior uveitis in these patients whereby intraocular EBV antibody production was found. We did test a small group of patients with anterior uveitis, but none showed evidence of EBV infection which may be due to the fact that our group of patients did not contain individuals with the entity as described by Usui and Sakai. ${ }^{8}$

Analysis of EBV DNA in our patients with uveitis also did not support a direct role for this virus in the pathogenesis of the intraocular inflammation in these cases. This conclusion is based on the fact that ocular viral DNA was found in $8 \%$ of "non-uveitic" control samples and in $5-10 \%$ of uveitis cases with known "other" infectious cause such as T gondii, VZV, $\mathrm{CMV}$, or HSV. In view of these findings a positive EBV PCR test result in our patient group with miscellaneous uveitis with an unknown cause was difficult to interpret.

Many investigators have been intrigued by the possible role of EBV in the pathogenesis of ocular inflammation. ${ }^{6-10}{ }^{20-26}$ The main problem in establishing direct proof is the ubiquitous presence of this virus. Until now, the evidence was mainly based on serological findings and not supported by viral culture or molecular biological analysis.

A recent study described the presence of EBV DNA in $50 \%$ of aqueous and $20 \%$ of vitreous samples taken from normal cadaveric eyes. ${ }^{27}$ We only found the EBV genome in $8 \%$ of the vitreous and in none of the aqueous samples taken from "non" uveitic eyes. The great difference between our results and those published by Chodosh et $a l^{27}$ is probably due to the sensitivity of the technique because they used Southern blotting and hybridisation with radioactive probes, whereas we only scored amplified products after electrophoresis and ethidium bromide staining of the agarose gel.

The increased presence of EBV in HIV negative immunocompromised patients could be due to either local reactivation of intraocular latent EBV or spreading of reactivated systemic EBV to various organs and tissues including the eye. B lymphocytes and various epithelial tissues are known to harbour latent EBV but, as yet, no intraocular site harvesting latent EBV has been reported. The local reactivation of EBV in this group of patients is probably due to the fact that they were severely immunocompromised as a result of the administration of various immunosuppressive drugs.

From our investigations on peripheral blood leucocytes and ocular fluid samples, we conclude that despite a broken blood-retinal barrier in the HIV positive patients and detectable EBV DNA in their PBLs, this does not necessarily lead to an influx of EBV into the eye. In the two patients positive for EBV DNA in both PBL and ocular fluid samples, the detection in the ocular fluid sample might have been the result of "overflow" from the peripheral blood. From the fact that the signal in the eye was clearly more positive than in the PBLs compared with a similar $\beta$ globin signal for both samples, we conclude that in those patients the presence of EBV in the eye may have been caused by a local reactivation. Further evidence of local reactivation should include mRNA analysis of EBV genes involved in reactivation of this virus. ${ }^{24}$

Detection of EBV DNA in other body fluids, such as cerebrospinal fluid, has been shown to predict the occurrence of primary central nervous system lymphoma in AIDS patients. ${ }^{28}$ Whether the detection of EBV DNA in intraocular fluids may also predict the presence of intraocular lymphoma in immunocompromised patients remains to be investigated. In series of immunocompromised patients we investigated so far, no intraocular lymphomas were observed.

Whether the presence of concomitant EBV influences the course of intraocular inflammation due to other causes such as Toxoplasma, VZV, HSV or CMV remains speculative. EBV is known to produce an active homologue of interleukin 10 and may also activate B lymphocytes to produce this immunosuppressive cytokine. ${ }^{29} 30$

Our current hypothesis is that EBV is not a direct cause of uveitis, but that it may well play a role as a secondary factor in the pathogenesis of uveitis. Analysis of virally expressed immunomodulatory factors (for example, a homologue to human IL-10) in the intraocular environment may improve our knowledge of this issue.

1 Tosato G, Taga K, Angiolillo AL, Sgadari C. Epstein-Barr virus as an agent of haematological disease. In: Young NS, ed. Viruses as agents of haematological disease. Baillière's clinical haematology. Vol 8(1). London: Baillière Tindall, 1995:165-99.

2 Tosato G, Steinberg AD, Yarchoan R, et al. Abnormally

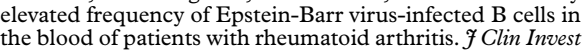
1984;73:1789-95.

3 Strauss SE. Epstein-Barr virus infections: biology, pathogenesis and management. Ann Intern Med 1993;118:45-58.

4 Birx DL, Redfield RR, Tosato G. Defective regulation of Epstein-Barr virus infection in patients with acquired immunodeficiency syndrome (AIDS) or AIDS-related disorders. N Engl f Med 1986;314:874-9.

5 Preiksatis JK, Diaz-Mitoma F, Mirzayans F, Roberts S, Tyrrell DLJ. Quantitative oropharyngeal EBV shedding in
renal and cardiac transplant recipients: Relationship to immunosuppressive therapy, serologic responses, and the risk of posttransplant lymphoproliferative disorder. F Infect Dis 1992;166:986-94.

6 Matoba AY, McCulley JP. Epstein-Barr virus and its ocular manifestations. In: Darrell RW, ed. Viral diseases of the eye. Philadelphia: Lea and Febiger, 1985:112-7.

7 Wong KW, D'Amico DJ, Hedges III TR, et al. Ocular involvement associated with chronic Epstein-Barr virus disease. Arch Ophthalmol 1987;105:788-92.

8 Usui M, Sakai J. Three cases of EB virus-associated uveitis. Int Ophthalmol 1990;14:371-6.

9 Tiedeman JS. Epstein-Barr viral antibodies in multifocal choroiditis and panuveitis. Am $\mathcal{f}$ Ophthalmol 1987;103: 659-63.

10 Matoba AY. Ocular disease associated with Epstein-Barr virus infection, review in medicine. Surv Ophthalmol 1990; 35:145-50.

11 Bloch-Michel E, Nussenblatt RB. International Uveitis Study Group. Recommendations for the evaluation of intra-ocular inflammatory disease. Am f Ophthalmol 1987; 103:234-5.

12 Holland GN, and the Executive Committee of the American Uveitis Society. Standard diagnostic criteria for the acute retinal necrosis. Am f Ophthalmol 1994;117:663-7.

13 Boom R, Sol CJA, Salimens MMM, Wertheim-van Dillen PME, van der Noordaa J. Rapid and simple method for purification of nucleic acids. 7 Clin Microbiol 1990;28:495-503.

14 Van Gorp J, Doornewaard H, Verdonck LF, et al. Posttransplant T-cell lymphoma: report of three cases and a review of the literature. Cancer 1994;73:3064-72. 
15 Longo MC, Berninger MS, Hartley JL. Use of uracil DNA glycosilase to control carryover contamination in polymerase chain reactions. Gene 1990;93:125-8

16 Boer de JH, Verhagen C, Bruinenberg M, et al. Serologic and polymerase chain reaction analysis of intra-ocular fluids in the diagnosis of infectious uveitis. Am $\mathcal{F}$ Ophthalmol 1996;121:650-8.

17 Saiki RK, Gelfland DH, Stoffel S, et al. Primer-directed enzymatic amplification of DNA with a thermostable enzymatic amplification of DNA with a
DNA-polymerase. Science 1988;239:487-91.

18 Luyendijk L, de Boer JH, Rothova A, et al. Sensitivity and specificity in antiviral antibody determination in the aqueous or vitreous of uveitis patients. In: Dernouchamps JP, ous or vitreous of uveitis patients. In: Dernouchamps JP,
Verougstraete C, Caspers-Velu L, Tassignon MJ, eds. Recent advances in uveitis. Amsterdam/New York: Kugler, 1992:265-7.

19 Miller G. Epstein-Barr virus. Biology, pathogenesis, and medical aspects. In: Fields BN, Knipe DM, eds. Virology. New York: Raven Press, 1990:1921-58.

20 Pflugfelder SC, Huang A, Crouse C. Epstein-Barr virus keratitis after a chemical facial peel. Am $\mathcal{F}$ Ophthalmol 1990;110:571-3.

21 Tsai CS, Ritch R, Strauss SE, Perry HD, Hsieh FY. Antibodies to Epstein-Barr virus in iridocorneal endothelial syndrome. Arch Ophthalmol 1990;108:1572-6.

22 Sunakawa M, Okinami S. Epstein-Barr virus-related antibody pattern in Uveitis. Fpn F Ophthalmol 1985;29:423-8.
23 Bernasconi ORE, Herbort CP. Epstein-Barr virus ocular disease: a difficult diagnosis. Klin Monatsbl Augenheilkd 1994;204:340-3.

24 Spaide RF, Sugin S, Yannuzzi LA, DeRosa JT. Epstein-Barr virus antibodies in multifocal choroiditis and panuveitis. Am f Ophthalmol 1991;112:410-3.

25 Pflugfelder SC, Crouse C, Pereira I, Atherton S. Amplification of Epstein-Barr virus genomic sequences in blood cells, lacrimal glands, and tears from primary Sjogren's syndrome patients. Ophthalmology 1990;97:976-84.

26 Grossniklaus HE, Aaberg TM, Purnell EW, Luka J, Seemayer TA. Retinal necrosis in X-linked lymphoproliferative disease. Ophthalmology 1994;104:705-8.

27 Chodosh J, Gan Y-J, Sixbey JW. Detection of Epstein-Barr virus genome in ocular tissues. Ophthalmology 1996;103: 687-90

28 Cinque P, Brytting $M$, Vago L, et al. Epstein-Barr virus DNA in cerebrospinal fluid from patients with AIDSrelated lymphoma of the central nervous system. Lancet 1993;342:398-401.

29 Vieira P, de Waal-Malefyt R, Dang MN, et al. Isolation and expression of human cytokine synthesis inhibitory factor CDNA clones: homology to Epstein-Barr virus open reading frame BCRF1. Proc Natl Sci USA 1991;88:1172-6.

30 Benjamin D, Park CD, Sharma V. Human B cell interleukin 10. Leukaemia and Lymphoma 1994;12:205-10. 